\title{
Mercury in Orange Birch Bolete Leccinum versipelle and soil substratum: bioconcentration by mushroom and probable dietary intake by consumers
}

\author{
Grażyna Krasińska $^{1} \cdot$ Jerzy Falandysz $^{1}$
}

Received: 18 May 2015 / Accepted: 27 August 2015 / Published online: 8 September 2015

(C) The Author(s) 2015. This article is published with open access at Springerlink.com

\begin{abstract}
The aim of this study was to examine the contamination, accumulation, and distribution of mercury in fruiting bodies by Leccinum versipelle fungus collected from distant sites across Poland. Mercury was determined using validated method by cold-vapor atomic absorption spectroscopy after direct sample matrix combustion. A large set of data gained using 371 fruiting bodies and 204 soil samples revealed the susceptibility of $L$. versipelle to $\mathrm{Hg}$ contamination and permitted the estimation of probable intake of $\mathrm{Hg}$ contaminant by consumers foraging for this species. The range of median values of $\mathrm{Hg}$ determined in caps of $L$. versipelle was from 0.20 to $2.0 \mathrm{mg} \mathrm{kg}^{-1}$ dry biomass, and the median for 19 localities was $0.65 \mathrm{mg} \mathrm{kg}^{-1}$ dry biomass. The values of the $\mathrm{Hg}$ bioconcentration factor $(\mathrm{BCF})$ determined for $L$. versipelle correlated negatively with $\mathrm{Hg}$ contents. Mercury in topsoil beneath $L$. versipelle ranged from 0.019 to $0.041 \mathrm{mg} \mathrm{kg}^{-1}$ dry matter for less-contaminated locations (BCF of 17 to 65 for caps) and from 0.076 to $0.39 \mathrm{mg} \mathrm{kg}^{-1}$ dry matter for more contaminated locations (BCF of 1.9 to 22). Fruiting bodies of L. versipelle collected in some regions of Poland if consumed in amount of $300 \mathrm{~g}$ in one meal in a week could provide $\mathrm{Hg}$ doses above the provisionally tolerable weekly intake (PTWI) value of $0.004 \mathrm{mg} \mathrm{Hg} \mathrm{kg}^{-1}$ body mass, while regular consumptions for most of the locations were below the limit even with more frequent consumption. Also summarized are available data on $\mathrm{Hg}$ for three species of fungi of genus Leccinum foraged in Europe.
\end{abstract}

\section{Responsible editor: Philippe Garrigues}

Jerzy Falandysz

jerzy.falandysz@ug.edu.pl

1 Laboratory of Environmental Chemistry \& Ecotoxicology, Gdańsk University, 63 Wita Stwosza Street, 80-308 Gdańsk, Poland
Keywords Foraging $\cdot$ Forest $\cdot$ Fungi $\cdot$ Mercury $\cdot$ Organic food $\cdot$ Soil

\section{Introduction}

The Orange Birch Bolete or red-capped scaber stalk Leccinum versipelle (Fr. \& Hök) Snell is one of macromycetes (mushrooms) in the Kingdom of Fungi that are popular in the Central and Eastern Europe and in the Scandinavia. Mushroom $L$. versipelle is also commonly known as Leccinum testaceoscabrum (Secr.) Sing. and is the most popular among the genus Leccinum collected in Poland (Gumińska and Wojewoda 1985). The fruiting body of the fungus, L. versipelle, is generally considered as good while its flesh quickly gets dark discoloration when it is hurt (cut), cooked (boiled/blanched and fried/roasted), or dried.

Another Leccinum species that is also common and annually foraged in Central and Eastern Europe is the Brown Birch Scaber Stalk Leccinum scabrum, but this is less valued and is usually dried before use because its stipe is somewhat tough and the mature fruiting body is smaller in size when compared to $L$ versipelle (Falandysz and Bielawski 2007; Falandysz et al. 2007c).

Fungi are numerous in species and habitats, and this makes it challenging to build up a reasonable and credible database on their chemical composition (Falandysz and Borovička 2013). Macromycetes pick up metallic elements and metalloids from soil and other substrates in which mycelia live. Some of them can efficiently accumulate, and some can also hyperaccumulate certain metallic elements, metalloids, or nonmetals in fruiting bodies, e.g., $\mathrm{Ag}, \mathrm{As}, \mathrm{V}$, and $\mathrm{Se}$, when they emerge at background areas (Borovička et al. 2007; Falandysz et al. 2007a; Stijve et al. 1990 and Stijve et al. 1998). The fruiting bodies of certain species can be also rich 
in mercury $(\mathrm{Hg})$ absorbed even from soil substrate whiteout $\mathrm{Hg}$ geochemical anomalies or anthropogenic pollution, and an example could be Macrolepiota procera or Boletus edulis, and some other Boletus mushrooms (Falandysz 2014; Falandysz et al. 2001b, 2003c, 2003d, 2007b, 2011, 2014b; Gucia et al. 2012; Melgar et al. 2009; Nasr et al. 2012; Ostos et al. 2015). Nevertheless, macromycetes differ in sequestration rate of $\mathrm{Hg}$ in fruiting bodies, and this could be considered as speciesspecific feature regardless of concentration in soil (Chudzyñski et al. 2009; Falandysz et al. 2014b and Falandysz et al. 2015c; Kojta et al. 2015; Krasińska and Falandysz 2015; Melgar et al. 2009; Nasr and Arp 2011).

The anthropogenic pollution of soils or other substrate with heavy metals (Ag, Hg), metalloids (As), or radionuclides $\left({ }^{137} \mathrm{Cs}\right.$ and others) usually causes their elevated accumulation in fruiting bodies of fungi (Falandysz et al. 1994a, 1994b, 2014a, 2015a and Falandysz et al. 2015b; García et al. 2015; Larsen et al. 1998). Fungi that grow on metallic/metalliferous soils or mine tailings can be specifically enriched in some elements (Ag, As, $\mathrm{Cd}, \mathrm{Hg}, \mathrm{Pb}$ ) accumulated in fruiting bodies (Mleczek et al. 2015; Kojta et al. 2012 and Kojta et al. 2015; Niedzielski et al. 2013; Řanda and Kučera 2004). Those from soils contaminated because of $\mathrm{Hg}$ mining can sequester $\mathrm{Hg}$ in the emerged fruiting bodies at level as high as $471 \mathrm{mg} \mathrm{kg}^{-1}$ dry matter (dm) as observed in Lactarius quietus (Árvay et al. 2014).

The place in soil substratum where the mycelium lives seems to be key in understanding the overriding sources of $\mathrm{Hg}$ to fungus - a mineral horizon or organic horizon with decaying layer at the surface and humus below. This could be disturbed by metallic element depositions from atmospheric fallout especially where the soil structure favors quicker vertical passage of the element small molecules under consideration into the deeper layers of the soil alongside with infiltrating rain, which now takes a portion of elements/minerals that were not readily adsorbed by litter and organic horizon of soil into deeper layers. Certain fungi form mycelium and rhizomorphs (root-like structures), which seem to coparticipate in the uptake and redistribution of $\mathrm{Hg}$ into fruiting bodies (Falandysz et al. 2013). Fungi having shallow mycelia can be efficient in the accumulation of airborne $\mathrm{Hg}$ deposited on the litter (Falandysz et al. 2014a).

Published data on annual rates of consumption of fungi collected from the wild by individuals are up to $20 \mathrm{~kg}$ per capita in the Great Britain and up to 20-24 kg per capita in Yunnan in China (Barnett et al. 1999; Zhang et al. 2010). Hence, the intake of minerals and other compounds contained in the flesh of fungi is of concern while our knowledge of their significance as sources of beneficial and noxious minerals is incomplete and worth of further study because of the high biodiversity of edible species and their wide distribution worldwide (Falandysz and Borovička 2013).

Mercury is a toxic chemical element, and because of the anthropogenic emissions of $\mathrm{Hg}$ into the atmosphere, it has recently become of greatest concern as a global contaminant of food and environment (Barnett et al. 1999; Blackwell and Driscoll 2015 ; Bushey et al. 2008; UNEP 2013). Many wildgrown fungi both of mycorrhizal and saprophytic nature can efficiently bioconcentrate $\mathrm{Hg}$ contained in substratum on which they emerge in their fruiting bodies (Drewnowska et al. 2012, 2014; Drewnowska and Falandysz 2015, 2014; Falandysz and Bielawski 2001; Falandysz and Brzostowski 2007; Fischer et al. 1995; Kojta et al. 2012; Rieder et al. 2011). The Hg contents in fruiting bodies of edible fungi are often elevated and much higher when compared to plants, while quantitative relationship on the redistribution of $\mathrm{Hg}$ between the mycorrhizal fungus and symbiont plant is not yet well known (Moore et al. 1995).

Foraging for edible and medicinal fruiting bodies of wildgrown fungi is a kind of gourmet tradition among various nations, while rates of consumption vary between the nations, populations, citizens and villages, families, and individuals (Barnett et al. 1999; Li et al. 2013; Nnorom et al. 2012; Petkovšek and Pokorny 2013; Tel et al. 2014). The L. versipelle is a mycorrhizal fungus, and the mycorrhizal fungi are known for their role in the redistribution of inorganic nutrients and other minerals to plants while many edible species are traditionally foraged from the wild in different regions of the world. This study aimed at elucidating the bioconcentration potential, distribution, and probable dietary intake and potential health risk for the local populations from $\mathrm{Hg}$ accumulated in fruiting bodies by $L$. versipelle, which emerged at 19 spatially and distantly distributed locations considered background areas (unpolluted forests) in Poland and which receive airborne $\mathrm{Hg}$ from global fallout that is dominated by anthropogenic emissions. The locations of material collection were without $\mathrm{Hg}$ parent soil bedrock anomaly. Also presented and discussed is a review of available data on $\mathrm{Hg}$ in this mushroom.

\section{Materials and methods}

Specimens of the L. versipelle (Fr. \& Hök) Snell fruiting bodies (371 individual samples) and 204 pooled samples of the upper 0-10-cm layer of forest soil (ca. $100 \mathrm{~g}$ ) beneath the specimens were collected from 19 spatially distant localities in Poland in the period 1998-2008 (Fig. 1; sampling details shown in Table 1). Any plant materials and particles of soil adhered to the mushroom were removed from the surface of the fruiting bodies, while bottom part of the stipe was cut off using a plastic knife. Thereafter, the fruiting bodies were subsequently air-dried at room temperature in a well-ventilated room for 2-3 days. Thereafter, they were dried in an electrically heated oven at $65{ }^{\circ} \mathrm{C}$ until constant weight under clean laboratory condition. Dried fruiting bodies (separately caps and stipes) were then crushed and ground to a fine powder in a porcelain mortar. The soil substrate samples were air-dried 


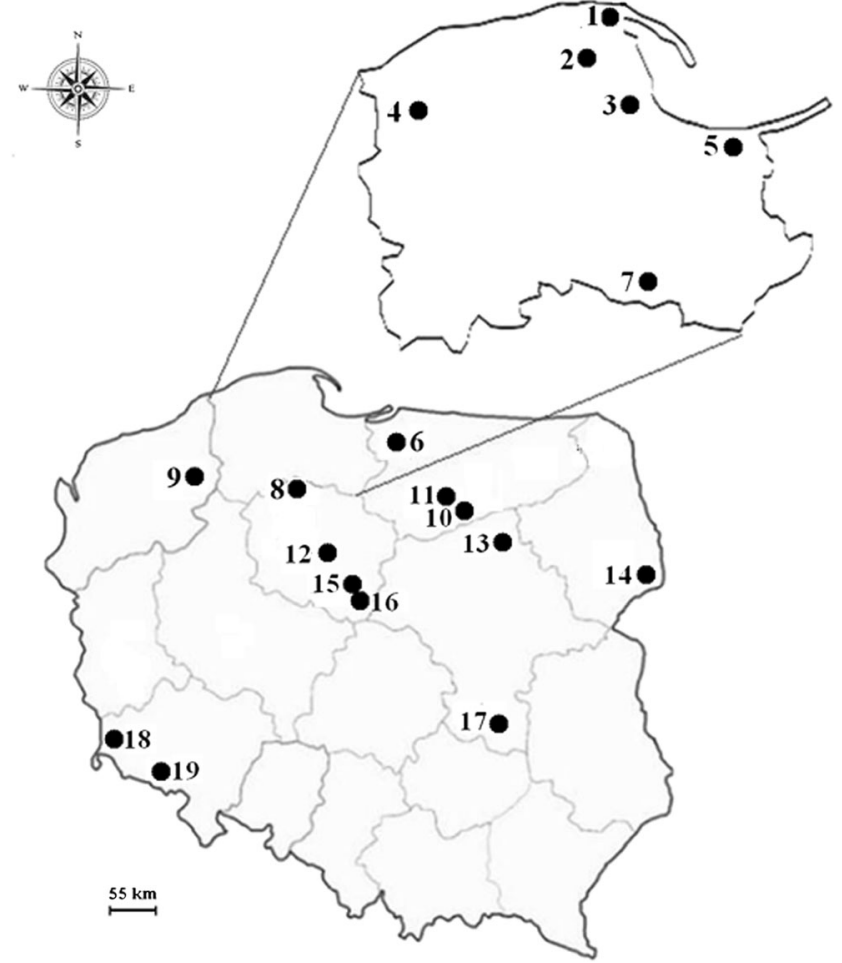

Fig. 1 Localization of the sampling sites (1-19) of L. versipelle (for details, see in Table 1)

at room temperature for approximately 10 weeks and then sieved through 2-mm sieve.

Total $\mathrm{Hg}$ content of the materials was determined after a direct sample thermal decomposition and released $\mathrm{Hg}$ vapor concentration measurement by cold-vapor atomic absorption spectroscopy (CV-AAS) (Mercury analyzer type MA-2, Nippon Instruments Corporation, Takatsuki, Japan). Analytical control and quality assurance (AC/QA) were performed by the analysis of certified reference material CS-M-1 (dried fruiting bodies of fungus Cow Bolete Suillus bovinus) and CS-M-4 (dried fruiting bodies of fungus Common Birch Stalk L. scabrum) produced by the Institute of Nuclear Chemistry and Technology in Warsaw, Poland. The Hg content of CS-M1 is certified as $0.174 \pm 0.018 \mathrm{mg} \mathrm{kg}^{-1} \mathrm{dm}$ and of CS-M-4 is certified as $0.465 \pm 0.024 \mathrm{Hg} \mathrm{mg} \mathrm{kg}^{-1} \mathrm{dm}$, while our measurement during the analysis of $L$. versipelle and the substrates showed $0.179 \pm 0.024 \mathrm{mg} \mathrm{kg}^{-1} \mathrm{dm}(n=23)$ for CS-M-1 and $0.449 \pm 0.026 \mathrm{mg} \mathrm{kg}^{-1} \mathrm{dm}$ for $(n=11)$ CS-M-4. For every set of ten fruiting bodies or soil samples analyzed, one blank sample was examined (Chudzyński et al. 2011; Jarzyńska and Falandysz 2011; Nnorom et al. 2013). The value of the quotient between $\mathrm{Hg}$ content of fruiting body and soils (the top layer in which mycelium develops and from which it takes up minerals) is considered as the bioconcentration factor (BCF) (Falandysz and Borovička 2013).

Table 1 summarizes information on $\mathrm{Hg}$ determinations ( $\mathrm{mg} \mathrm{kg}^{-1}$ dry matter $(\mathrm{dm})$ ) in $L$. versipelle and soil substratum as well as the calculated values of quotient of $\mathrm{Hg}$ in cap to stipe concentration $\left(Q_{\mathrm{C} / \mathrm{S}}\right)$ and the bioconcentration factor (BCF) from this study. Table 2 summarizes the available data on occurrence on $\mathrm{Hg}$ in morphological parts or whole fruiting bodies of three species of genus Leccinum (Leccinum rufum, L. scabrum, and L. versipelle) collected in Europe. The analytical results were statistically treated using computer software Statistica (version 8.0) by StatSoft. Because mercury concentration in fruiting bodies has no Gaussian distribution (Chudzyñski et al. 2009), the possible statistically significant differences between the variables were examined with the aid of the nonparametric Mann-Whitney $U$ test.

\section{Results and discussion}

\section{Contents and efficiency of $\mathrm{Hg}$ sequestering in $L$. versipelle fruiting body}

The values of $\mathrm{Hg} \mathrm{BCF}$ for all samples (specimens) in this study were above 1 , and for some of the sites, the median values for caps were up to 65 (Table 1). This implies that there is a good bioconcentration potential of $\mathrm{Hg}$ by $L$. versipelle. The absorption of $\mathrm{Hg}$ by this fungus from sources other than soils, i.e., air, due to airborne deposition of $\mathrm{Hg}$ onto the surface of fruiting bodies can be neglected. This is because the concentration of $\mathrm{Hg}$ in atmospheric air over the background (uncontaminated) areas and regions of the World is low, e.g., in Europe is from 2 to $3 \mathrm{ng}$ per cubic meter in summer and from 3 to 4 ng per cubic meter in winter, and for the urbanized areas, this is about 3-4-fold higher (WHO 2000). The fruiting bodies of macromycetes emerge quickly and, depending on species, become matured in one or more days, and their lifetime is relatively short.

In aquatic environment, methylmercury in a complex with amino acid cysteine is well accumulated and biomagnified by biota in a food chain (UNEP 2013). This remains unknown for fungi. Both inorganic $\mathrm{Hg}$ and $\mathrm{MeHg}$ are efficiently accumulated by numerous species of mushrooms (Stijve and Roschnik 1974). An inorganic $\mathrm{Hg}$ is the dominant form in the total $\mathrm{Hg}$ sequestered in fruiting bodies while $\mathrm{MeHg}$ is minor. For example, in Leccinum griseum, the $\mathrm{MeHg}$ accounted at $0.5 \%$ in total $\mathrm{Hg}$ (Rieder et al. 2011), while no such data are available for $L$. versipelle.

The reported values of the Hg BCF determined for caps and stipes of $L$. versipelle correlated negatively with the median values of $\mathrm{Hg}$ content in the top fraction of soils which, for four sites, ranged from 0.076 to $0.39 \mathrm{mg} \mathrm{kg}^{-1} \mathrm{dm}$ (BCF of 1.9-22 for caps) and, for 14 other sites, ranged from 0.019 to $0.041 \mathrm{mg} \mathrm{kg}^{-1} \mathrm{dm}$ (BCF of 17-65 for caps) (Table 1).

Earlier, it has been found that efficiency of $\mathrm{Hg}$ inclusion into fruiting bodies by certain fungi that emerged at an "unpolluted" soil occurred with considerably greater 


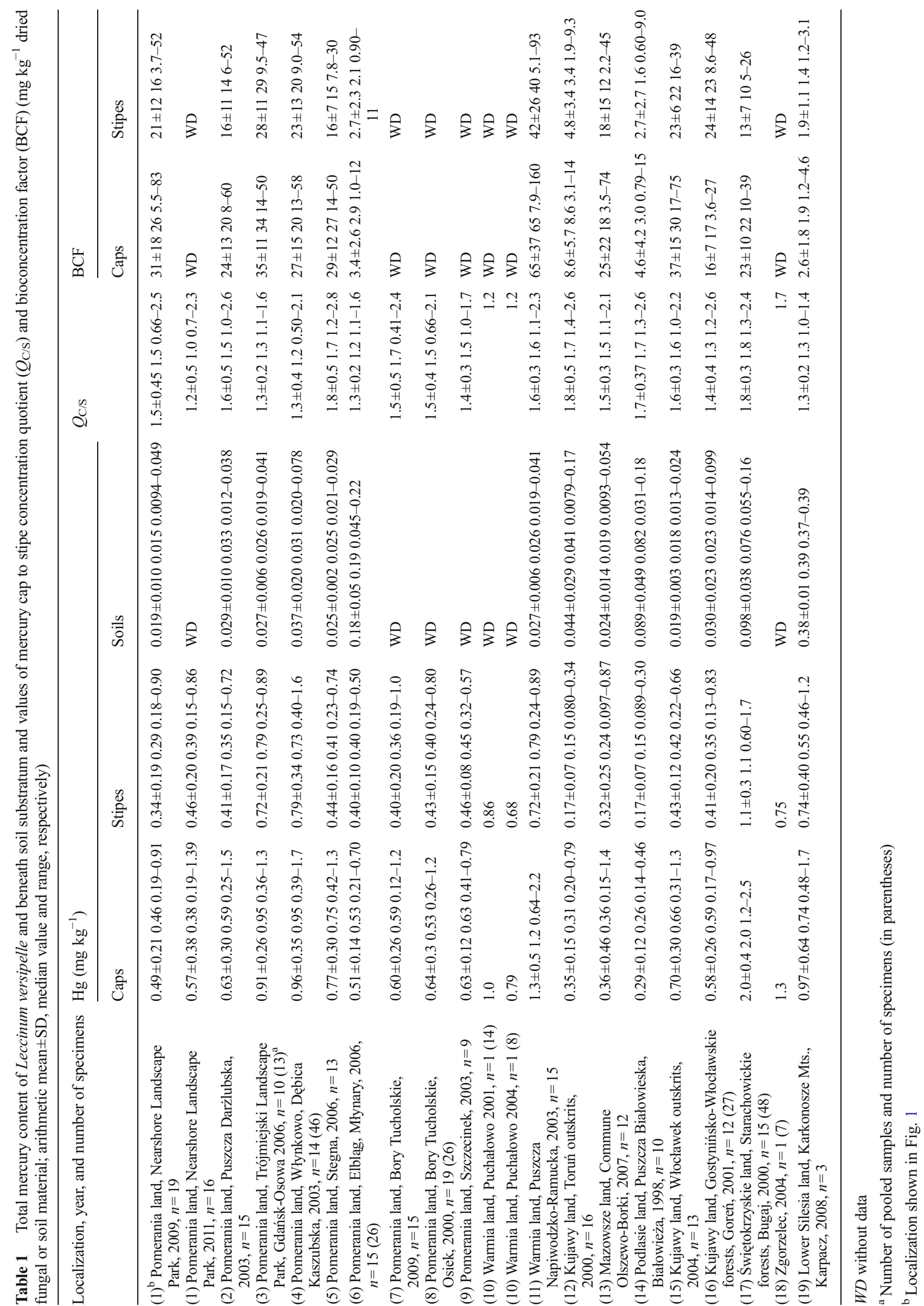


efficiency compared to those that emerged at "polluted" areas (Falandysz et al. 2012a, 2012b, 2012c, 2012d). This could be observed also for $L$. versipelle from Puszcza NapiwodzkoRamucka and the Starachowicki forests in this study, which contained $\mathrm{Hg}$, respectively, in caps at $1.3 \pm 0.5$ and $2.0 \pm$ $0.4 \mathrm{mg} \mathrm{kg}^{-1} \mathrm{dm}$ and in stipes at $0.72 \pm 0.21 \mathrm{mg} \mathrm{kg}^{-1} \mathrm{dm}$, while efficiency of inclusion measured by value of BCF was $65 \pm 37$ and $23 \pm 10$ (caps) and $42 \pm 26$ and $13 \pm 7$ (stipes), and soil $\mathrm{Hg}$ was at $0.027 \pm 0.006$ and $0.098 \pm 0.038 \mathrm{mg} \mathrm{kg}^{-1} \mathrm{dm}$.

There was a clear difference $(0.001<p<0.05$; MannWhitney $U$ test) in $\mathrm{Hg}$ contamination of both the caps and stipes of $L$. versipelle for some of the sites studied, and range for caps was from $0.29 \pm 0.12 \mathrm{mg} \mathrm{kg}^{-1} \mathrm{dm}$ (Puszcza Białowieska) to $2.0 \pm 0.4 \mathrm{mg} \mathrm{kg}^{-1} \mathrm{dm}$ (Starachowickie forests) and for stipes from $0.17 \pm 0.07$ to $1.1 \pm 0.3 \mathrm{mg} \mathrm{kg}^{-1} \mathrm{dm}$, while for majority of the specimens, $\mathrm{Hg}$ content for caps was around $0.6 \mathrm{mg} \mathrm{kg}^{-1} \mathrm{dm}$ and that of stipes about $0.4 \mathrm{mg} \mathrm{kg}^{-1} \mathrm{dm}$ (Table 1).

The L. versipelle (Tables 1 and 2) and many other species of wild-grown fungi are substantially more enriched with $\mathrm{Hg}$ compared to the edible plants (leafy vegetables, fruits, tubers, and grains) or tissues and organs of slaughtered animals as well as in certain sea foods (Falandysz 1994; Falandysz et al. 1994c; Guédron et al. 2014; Varo et al. 1980). Hence, fruiting bodies of $L$. versipelle can be of a concern as a source of exposure to $\mathrm{Hg}$ by consumers.

\section{$\mathrm{Hg}$ in some Leccinum spp. and Hg intake}

Generally, the fruiting bodies (and also the sclerotia) of edible fungi collected from the wild are considered as delicacy and even as having a medicinal value in various parts of the World (Dai et al. 2013; Nnorom et al. 2013). The species L. versipelle as well as $L$. rufum and young $L$. scabrum are tasty, popular, and valuable wild-grown fungi used traditionally as gourmet in Central and Eastern Europe and in Scandinavia. The Yunnan land of China has a wide variety of species and dishes of fungi (Wang et al. 2014). Similarly, within the "Western" societies, the wild-grown fungi are also components of rather exclusive meals (Lassoe et al. 1996).

Amongst of the Leccinum mushrooms that are edible and popular in the Central and Eastern Europe and Scandinavia, apart from the $L$. versipelle, are species such as $L$. scabrum (Bull.: Fr.) S.F. Gray and L. rufum (Schaeff.) Kreisel, which was also called Leccinum aurantiacum (Bull.) Gilb., and less or much less frequent are Leccinum pseudoscabrum (Kallenb.) Šutara [earlier known as L. griseum (Quél.) Singer 1966 and Leccinum carpini (R. Schulz) M.M. Moser ex D.A. Reid 1965], Leccinum variicolor Watling 1969, Leccinum vulpinum Watl., Leccinum piceinum Pilát \& Derm., Leccinum quercinum (Pilát) Green et al. Watl., and Leccinum duriusculum (Kalchbr.) (Singer, 1947) (Gumińska and Wojewoda 1985; Jarzyńska and Falandysz 2012a, 2012b).
Data available on $\mathrm{Hg}$ content and distribution in fruiting bodies of L. rufum, L. scabrum, and L. versipelle collected in Europe and including unidentified Leccinum sp. from Turkey are summarized in Table 2.

As can be noted from Table 2, in several studies with different number of specimens and localities examined, the species $L$. rufum with the $\mathrm{Hg}$ median values in caps from 0.18 to $1.7 \mathrm{mg} \mathrm{kg}^{-1} \mathrm{dm}$ and L. scabrum with from 0.11 to $1.2 \mathrm{mg} \mathrm{kg}^{-1}$ $\mathrm{dm}$, all showed roughly similar contents of $\mathrm{Hg}$ as found in $L$. versipelle in this study. One exception from that pattern seems to be a median value of $7.3 \mathrm{mg} \mathrm{kg}^{-1} \mathrm{dm}$ reported for caps of $L$. scabrum from one site that was considered as being under anthropogenic impacts and most probably related to the World War II and/or other military activities in the past (Table 2). Hence, in general, an intake and risk from $\mathrm{Hg}$ contained in flesh of these species mirror comments drawn above for $L$. versipelle.

Loss of $\mathrm{Hg}$ from the flesh of fungi when cooked is relatively low (around $10 \%$ ) if an ordinary processing procedure (e.g., blanching for $10 \mathrm{~min}$ ) is applied (Falandysz and Drewnowska 2015), and this needs further studies because of several procedures known (freezing, frying, grilling, pickling, salting/souring) with possible impact on $\mathrm{Hg}$ and other trace elements and minerals content of cooked fruiting bodies.

\section{L. versipelle and $\mathrm{Hg}$ intake}

For the assessment of the risks due to intake of inorganic $\mathrm{Hg}$ from food, one of the parameters used is the $\mathrm{Hg}$ reference dose (RfD) of $0.0003 \mathrm{mg} \mathrm{kg}^{-1}$ body mass (bm) daily (US EPA 1987). For this purpose, the provisional tolerable weekly intake (PTWI) of THg is also used (i.e., $0.004 \mathrm{mg} \mathrm{kg}^{-1} \mathrm{bm}$ ) (JECFA 2010).

Because of the important biological and geochemical interactions of $\mathrm{Hg}$ and selenium (Se), it was suggested recently that the assessment of risk from $\mathrm{Hg}$ should consider the interaction between Hg and Se (Ralston and Raymond 2014; Zhang et al. 2014). Selenium is at ultra-trace levels in food and is essential at very small amounts, while there is a high risk of toxicity if taken in excess. Selenium is an antagonist to MeHg and inorganic $\mathrm{Hg}$, which is toxic, but a common contaminant of foods which at ultra-trace level is considered without biological effect. A possible protective role of Se against the biological activity of $\mathrm{Hg}$ contained in mushrooms and vice versa is worth of future studies.

In some nations, the edible sclerotia of some fungi are also popular (Nnorom et al. 2013; Wang et al. 2015). Apart from the different consumption patterns of fungi between individuals and populations worldwide, another factor involving variability is the earlier mentioned biodiversity of species with many having, to some extent, a cosmopolitan character while others are having more local or regional distribution. Another variable is the distinct differences in natural contents of 
Table 2 Mercury ( $\mathrm{mg} \mathrm{kg}^{-1}$ dry biomass) in certain mushrooms of genus Leccinum in Europe (adapted)

\begin{tabular}{|c|c|c|c|c|}
\hline Species, year(s), part of fruiting body, and number of individuals & Mean $/ \mathrm{s} \pm \mathrm{SD}$ & Median/s & Total range & Reference \\
\hline L. rufum (caps), 1997/1998, $n=117$ & $0.60 \pm 0.59-1.8 \pm 0.6$ & $0.51-1.7$ & $0.28-2.8$ & abcde \\
\hline L. rufum (caps), 2004/2006, $n=126$ & $0.27 \pm 0.07-1.3 \pm 0.6$ & $0.28-1.3$ & $0.16-2.2$ & f \\
\hline L. rufum (stipes), 1997/1998, $n=117$ & $0.45 \pm 0.24-1.7 \pm 0.6$ & $0.42-1.6$ & $0.067-2.7$ & abcde \\
\hline L. rufum (stipes), 2004/2006, $n=126$ & $0.19 \pm 0.06-0.58 \pm 0.08$ & $0.18-0.54$ & $0.077-0.89$ & $\mathrm{f}$ \\
\hline L. scabrum (caps), 1994, $n=16$ & $0.37 \pm 0.33$ & 0.27 & $0.093-1.2$ & $\mathrm{~g}$ \\
\hline L. scabrum (caps), 1994, $n=16$ & $0.29 \pm 0.30$ & 0.20 & $0.12-1.3$ & $\mathrm{~h}$ \\
\hline L. scabrum (caps), 1993/1994, $n=14$ & $0.29 \pm 0.10$ & 0.28 & $0.14-0.46$ & $\mathrm{i}$ \\
\hline L. scabrum (caps), 1995, $n=19$ & $0.18 \pm 0.13$ & 0.19 & $0.033-0.47$ & j \\
\hline L. scabrum (caps), 1995, $n=15$ & $0.50 \pm 0.23$ & 0.46 & $0.17-0.93$ & k \\
\hline L. scabrum (caps), 1997/1998, $n=12$ & $6.7 \pm 2.2$ & 7.3 & $3.2-9.6$ & 1 \\
\hline L. scabrum (caps), 1998/2001, $n=240$ & $0.38 \pm 0.23-1.2 \pm 0.4$ & $0.36-1.2$ & $0.072-2.0$ & $\mathrm{~m}$ \\
\hline L. scabrum (stipes), 1994, $n=16$ & $0.22 \pm 0.16$ & 0.17 & $0.050-0.65$ & $\mathrm{~g}$ \\
\hline L. scabrum (caps), 1994, $n=16$ & $0.18 \pm 0.16$ & 0.14 & $0.052-0.64$ & $\mathrm{~h}$ \\
\hline L. scabrum (stipes), 1993/1994, $n=14$ & $0.18 \pm 0.06$ & 0.18 & $0.061-0.29$ & $\mathrm{i}$ \\
\hline L. scabrum (stipes), 1995, $n=19$ & $0.10 \pm 0.06$ & 0.11 & $0.015-0.21$ & $\mathrm{j}$ \\
\hline L. scabrum (stipes), 1995, $n=15$ & $0.32 \pm 0.13$ & 0.30 & $0.14-0.64$ & $\mathrm{k}$ \\
\hline L. scabrum (stipes), 1997/1998, $n=12$ & $4.6 \pm 1.7$ & 4.6 & $1.7-7.7$ & 1 \\
\hline L. scabrum (stipes), 1998/2001, $n=240$ & $0.17 \pm 0.07-1.1 \pm 0.3$ & $0.080-1.1$ & $0.034-1.7$ & $\mathrm{~m}$ \\
\hline L. scabrum(h/rfb), 2005/2006, $n=6$ & $0.57 \pm 0.23 / 0.44 \pm 0.31$ & - & - & $\mathrm{n}$ \\
\hline L. scabrum (whole fruit bodies) $n=15$ & $0.33 \pm 0.21$ & 0.24 & $0.13-0.93$ & d \\
\hline L. versipelle (whole), p. 1976 & 0.37 & - & $0.27-0.45$ & o \\
\hline L. versipelle (caps), 1995/1997, $n=15$ & $0.46 \pm 0.04$ & 0.35 & $0.080-1.7$ & a \\
\hline L. versipelle (caps), 1995, $n=13$ & $0.50 \pm 0.31$ & 0.51 & $0.010-1.2$ & $\mathrm{i}$ \\
\hline L. versipelle (caps), 1997/1998, $n=16$ & $0.72 \pm 0.38$ & 0.67 & $0.28-1.7$ & $\mathrm{p}$ \\
\hline L. versipelle (caps), 1998/2008, $n=257$ & $0.20 \pm 0.07-2.0 \pm 0.4$ & $0.20-2.0$ & $0.14-2.5$ & This study \\
\hline L. versipelle (stipes), 1995/1997, $n=31$ & $0.25 \pm 0.22$ & 0.14 & $0.052-0.91$ & a \\
\hline L. versipelle (stipes), 1995, $n=13$ & $0.30 \pm 0.23$ & 0.30 & $0.057-0.94$ & $\mathrm{i}$ \\
\hline L. versipelle (caps), 1997/1998, $n=16$ & $0.42 \pm 0.38$ & 0.43 & $0.16-0.89$ & $\mathrm{p}$ \\
\hline L. versipelle (stipes), 1998/2008, $n=257$ & $0.17 \pm 0.07-1.1 \pm 0.3$ & $0.080-1.1$ & $0.034-1.7$ & This study \\
\hline Leccinum sp. (whole), p. 1998 & 0.26 & & q & \\
\hline
\end{tabular}

$h / r f b$ hymenophore/rest of fruit body, $p$. year of publication

${ }^{\mathrm{a}}$ Falandysz (2002)

${ }^{\mathrm{b}}$ Falandysz et al. (2002b)

${ }^{\mathrm{c}}$ Falandysz et al. (2003a)

${ }^{\mathrm{d}}$ Falandysz et al. (2002c)

${ }^{\text {e }}$ Falandysz et al. (2004)

${ }^{\mathrm{f}}$ Falandysz et al. (2012b)

${ }^{g}$ Falandysz et al. (1996)

${ }^{\text {h }}$ Falandysz and Kryszewski (1996)

${ }^{\text {i }}$ Falandysz and Chwir (1997)

${ }^{\mathrm{j}}$ Falandysz et al. (2001a)

${ }^{\mathrm{k}}$ Falandysz et al. (2003c)

${ }^{1}$ Falandysz et al. 2003b

${ }^{\mathrm{m}}$ Falandysz and Bielawski 2007

${ }^{\mathrm{n}}$ Melgar et al. (2009)

${ }^{\circ}$ Seeger and Nützel (1976)

${ }^{\mathrm{p}}$ Falandysz et al. (2002a)

${ }^{\mathrm{q}}$ Tüzen et al. (1998) 
particular elements in mature fruiting bodies of a given species of fungus that emerged at spatially distant sites as shown for $\mathrm{Hg}$ and L. versipelle in this study (Table 1). Data concerning spatial differences and similarities in fruiting body contents of $\mathrm{Hg}$ or other trace elements and minerals are rarely published (Brzostowski et al. 2011a and Brzostowski et al. 2011b; Chojnacka et al. 2012, 2013; Chudzyński and Falandysz 2008; Falandysz et al. 2007a, 2007b, 2007d).

It is reasonable to assume that an average amount of fresh fruiting bodies consumed in a meal by a fancier is $300 \mathrm{~g}$ while some could consume as much as $500 \mathrm{~g}$ (Chudzyński et al. 2011). For some individuals who may be characterized by the maximum annual consumption of wild-grown fungi (estimated at $20-24 \mathrm{~kg}$ as reported until now), the annual intake would be from around 67 to 80 meals each of 300 -g fruiting bodies.

In this study, the range of median values of $\mathrm{Hg}$ determined in caps of $L$. versipelle per site was from 0.20 to $2.0 \mathrm{mg} \mathrm{kg}^{-1} \mathrm{dm}$ and the median value for all 19 localities was $0.65 \mathrm{mg} \mathrm{kg}^{-1} \mathrm{dm}$ (Table 1). Assuming that moisture content of the fresh fruiting body is $90 \%$, the contents of $\mathrm{Hg}$ for fresh caps are $0.02,0.20$, and $0.065 \mathrm{mg} \mathrm{kg}^{-1}$, respectively, and around 1.5 -fold less in the stipes.

A meal made of $300 \mathrm{~g}$ of fresh caps of $L$. versipelle from the areas examined could provide from 0.006 to $0.060 \mathrm{mg}$ $\mathrm{Hg}$ (a dose of 0.0001 to $0.0010 \mathrm{mg} / \mathrm{kg}$ bm for person of $60 \mathrm{~kg} \mathrm{bm}$ ), and the median $\mathrm{Hg}$ intake for all 19 locations studied would be $0.0195 \mathrm{mg}\left(0.000325 \mathrm{mg} \mathrm{kg}^{-1} \mathrm{bm}\right)$ assuming no $\mathrm{Hg}$ intake from other sources. Theoretically, if eaten daily, the Hg intake rate calculated for the "average" and "maximum" contaminated mushrooms is equal to or exceeds the RfD value by 3 -fold. Nevertheless, fruiting bodies of wild-grown fungi are not eaten daily even by fanciers or villagers in Poland but certainly can be eaten by them more frequently in mushrooming season that is from July to October.

In light of the value of PTWI for inorganic $\mathrm{Hg}$, one meal consisting of caps of $L$. versipelle for the sites contaminated at the average or maximum level as shown in this study will provide $\mathrm{Hg}$ at 20 to $60 \%$ of the PTWI. Hence, depending on the area of fungi pickup, more than one meal in a week could result in exceeding the PTWI. A less-frequent consumption could be considered safe.

\section{Conclusions}

The Orange Birch Bolete (L. versipelle) has good potential to accumulate $\mathrm{Hg}$ from soils. Specimens of this $L$. versipelle collected at background (unpolluted) areas in Poland showed $\mathrm{Hg}$ at levels that could be considered as safe and probably representative for species in this part of Europe.
Acknowledgments This study is a part of $\mathrm{PhD}$ thesis by Grażyna Krasińska and was financially supported to by the National Science Centre of Poland under project no. DEC-2011/03/N/NZ9/04136. Technical help by Agnieszka Dubiel, Joanna Draheim, Joanna Gozdek, Aleksandra Jabłońska, Katarzyna Janukowicz, Magdalena Kulaszewska, Monika Mokrecka, Aleksandra Mostrąg, Anna Orlikowska, Alina Pękacka, Elżbieta Rafał, Aleksandra Rogińska, Magdalena Roszak, Aleksandra Stefańska, Joanna Ziółkowska, and Łukasz Zegarowski is acknowledged.

Open Access This article is distributed under the terms of the Creative Commons Attribution 4.0 International License (http:// creativecommons.org/licenses/by/4.0/), which permits unrestricted use, distribution, and reproduction in any medium, provided you give appropriate credit to the original author(s) and the source, provide a link to the Creative Commons license, and indicate if changes were made.

\section{References}

Árvay J, Tomáša J, Hauptvogl M, Kopernická M, Kováčik A, Bajčan D, Massányi P (2014) Contamination of wild-grown edible mushrooms by heavy metals in a former mercury-mining area. J Environ Sci Health Part B 49:815-827

Barnett CL, Beresford NA, Frankland JC, Self PL, Howard BJ, Marriott JVR (1999) Radiocaesium activity concentrations in the fruit-bodies of macrofungi in Great Britain and an assessment of dietary intake habits. Sci Total Environ 231:67-83

Blackwell BD, Driscoll CT (2015) Using foliar and forest floor mercury concentrations to assess spatial patterns of mercury deposition. Environ Poll 202:126-134

Borovička J, Řanda Z, Jelínek E, Kotrba P, Dunn CE (2007) Hyperaccumulation of silver by Amanita strobiliformis and related species of the section Lepidella. Mycol Res 111:1339-1344

Brzostowski A, Falandysz J, Jarzyńska G, Zhang D (2011a) Bioconcentration potential of metallic elements by Poison Pax (Paxillus involutus) mushroom. J Environ Sci Health Pt A 46:378393

Brzostowski A, Jarzyńska G, Kojta AK, Wydmańska D, Falandysz J (2011b) Variations in metal levels accumulated in Poison Pax (Paxillus involutus) mushroom collected at one site over four years. J Environ Sci Health Part A 46:581-588

Bushey JT, Nallana AG, Montesdeoca MR, Driscoll CT (2008) Mercury dynamics of a northern hardwood canopy. Atmos Environ 42:69056914

Chojnacka A, Jarzyńska G, Drewnowska M, Nnorom IC, Falandysz J (2012) Yellow-cracking Boletes (Xerocomus subtomentosus) mushrooms: content and potential to sequestrate mercury. J Environ Sci Health Part A 47:2094-3011

Chojnacka A, Jarzyńska G, Lewandowska M, Nnorom IC, Falandysz J (2013) Multivariate analysis of minerals in yellow-cracking Bolete (Xerocomus subtomentosus) collected at one site over three years. Fresenius Environ Bull 22:2707-2712

Chudzyński A, Falandysz J (2008) Multivariate analysis of elements content of Larch Bolete (Suillus grevillei) mushroom. Chemosphere 73:1230-1239

Chudzyñski K, Bielawski L, Falandysz J (2009) Mercury bioconcentration potential of Larch Bolete, Suillus grevillei, mushroom. Bull Environ Contam Toxicol 83:275-279

Chudzyński K, Jarzyńska G, Stefańska A, Falandysz J (2011) Mercury content and bio-concentration potential of Slippery Jack, Suillus luteus, mushroom. Food Chem 125:986-990

Dai Y-C, Bau T, Cui B-K, Qin G-F (2013) Illustrations of medicinal fungi in China (In Chinese). Northeast Forestry University Press, Harbin 
Drewnowska M, Falandysz J (2015) Investigation on minerals composition and accumulation by popular edible mushroom Common Chanterelle (Cantharellus cibarius). Ecotoxicol Environ Saf 113: 9-17

Drewnowska M, Jarzyńska G, Kojta AK, Falandysz J (2012) Mercury in European Blusher, Amanita rubescens, mushroom and soil. Bioconcentration potential and intake assessment. J Environ Sci Health Part B 47:466-474

Drewnowska M, Nnorom IC, Falandysz J (2014) Mercury in the Tawny Grisette, Amanita vaginata Fr. and soil below the fruiting bodies. J Environ Sci Health Part B 49:521-526

Dryżałowska A, Falandysz J (2014) Bioconcentration of mercury by mushroom Xerocomus chrysenteron from the spatially distinct locations: levels, possible intake and safety. Ecotoxicol Environ Saf 107: 97-102

Falandysz J (1994) Some toxic and trace-metals in big game hunted in the northeastern part of Poland in 1987-1991. Sci Total Environ 141: $59-73$

Falandysz J (2002) Mercury in mushrooms and soil of the Tarnobrzeska Plain, southeastern Poland. J Environ Sci Health Part A 37:343-352

Falandysz J (2014) Distribution of mercury in Gypsy Cortinarius caperatus mushrooms from several populations: an efficient accumulator species and estimated intake of element. Ecotoxicol Environ Saf 110:68-72

Falandysz J, Bielawski L (2001) Mercury content of wild edible mushrooms collected near the town of Augustów. Polish J Environ Stud 10:67-71

Falandysz J, Bielawski L (2007) Mercury and its bioconcentration factors in Brown Birch Scaber Stalk (Leccinum scabrum) from various sites in Poland. Food Chem 105:635-640

Falandysz J, Borovička J (2013) Macro and trace mineral constituents and radionuclides in mushrooms - health benefits and risks. Appl Microbiol Biotechnol 97:477-501

Falandysz J, Brzostowski A (2007) Mercury and its bioconcentration factors in Poison Pax (Paxillus involutus) from various sites in Poland. J Environ Sci Health Part A 42:1095-1100

Falandysz J, Chwir A (1997) The concentrations and bioconcentration factors of mercury in mushrooms from the Mierzeja Wiślana sandbar, Northern Poland. Sci Total Environ 203:221-228

Falandysz J, Drewnowska M (2015) Distribution of mercury in Amanita fulva (Schaeff.) Secr. mushrooms: accumulation, loss in cooking and dietary intake. Ecotoxicol Environ Saf 115:9-54

Falandysz J, Kryszewski K (1996) Rtęć w grzybach i substracie spod grzybów z okolic Polanowic w gminie Gubin, województwo zielonogórskie. Roczn Państw Zakł Hig 47:377-388

Falandysz J, Bona H, Danisiewicz D (1994a) Silver uptake by Agaricus bisporus from an artificially enriched substrate. Lebensm Unters Forsch 199:225-228

Falandysz J, Bona H, Danisiewicz D (1994b) Silver content of wildgrown mushrooms from Northern Poland. Lebensm Unters Forsch 199:222-224

Falandysz J, Kotecka W, Kannan K (1994c) Mercury, lead, cadmium, manganese, copper, iron and zinc concentrations in poultry, rabbit and sheep from the northern part of Poland. Sci Total Environ 141: $51-57$

Falandysz J, Marcinowicz A, Chwir A (1996) Rtêæ w jadalnych grzybach z terenu lasów koœcierskich i Mierzei Wiœlanej. Rocz Pañstw Zakł Hig 47:205-210

Falandysz J, Gucia M, Frankowska A, Kawano M, Skwarzec B (2001a) Total mercury in wild mushrooms and underlying soil substrate from the city of Umeå and its surroundings, Sweden. Bull Environ Contam Toxicol 67:763-770

Falandysz J, Szymczyk K, Ichihashi H, Bielawski L, Gucia M, Frankowska A, Yamasaki S (2001b) ICP/MS and ICP/AES elemental analysis (38 elements) of edible wild mushrooms growing in Poland. Food Addit Contam 18:503-513
Falandysz J, Bielawski L, Kannan K, Gucia M, Lipka K, Brzostowski A (2002a) Mercury in wild mushrooms and underlying soil substrate from the great lakes land in Poland. J Environ Monit 4:473-476

Falandysz J, Gucia M, Skwarzec B, Frankowska A, Klawikowska K (2002b) Total mercury in mushrooms and underlying soil from the Borecka Forest, Northeastern Poland. Arch Environ Contam Toxicol 42:145-154

Falandysz J, Lipka K, Gucia M, Kawano M, Strumnik K, Kannan K (2002c) Accumulation factors of mercury in mushrooms from Zaborski Landscape Park, Poland. Environ Intern 28:421-427

Falandysz J, Brzostowski A, Kawano M, Kannan K, Puzyn T, Lipka K (2003a) Concentrations of mercury in wild growing higher fungi and underlying substrate near Lake Wdzydze, Poland. Water Air Soil Pollution 148:127-137

Falandysz J, Gucia M, Brzostowski A, Kawano M, Bielawski L, Frankowska A, Wyrzykowska B (2003b) Content and bioconcentration of mercury in mushrooms from northern Poland. Food Addit Contam 20:247-253

Falandysz J, Kawano M, Świeczkowski A, Brzostowski A, Dadej M (2003c) Total mercury in wild-grown higher mushrooms and underlying soil from Wdzydze Landscape Park, Northern Poland. Food Chem 81:21-26

Falandysz J, Lipka K, Kawano M, Brzostowski A, Dadej M, Jędrusiak A, Puzyn T (2003d) Mercury content and its bioconcentration factors at Łukta and Morag, Northeastern Poland. J Agricult Food Chem 51: 835-2836

Falandysz J, Jędrusiak A, Lipka K, Kannan K, Kawano M, Gucia M, Brzostowski A, Dadej M (2004) Mercury in wild mushrooms and underlying soil substrate from Koszalin, North-central Poland. Chemosphere 54:461-466

Falandysz J, Lipka K, Mazur A (2007a) Mercury and its bioconcentration factors in Fly Agaric (Amanita muscaria) from spatially distant sites in Poland. J Environ Sci Health Part A 42:1625-1630

Falandysz J, Kunito T, Kubota R, Brzostowski A, Mazur A, Falandysz JJ, Tanabe S (2007b) Selected elements of Poison Pax Paxillus involutus. J Environ Sci Health Part A 42:1161-1169

Falandysz J, Kunito T, Kubota R, Bielawski L, Mazur A, Falandysz JJ, Tanabe S (2007c) Selected elements in Brown Birch Scaber Stalk Leccinum scabrum. J Environ Sci Health Part A 42:2081-2088

Falandysz J, Kunito T, Kubota R, Lipka K, Mazur A, Falandysz JJ, Tanabe S (2007d) Selected elements in Fly Agaric Amanita muscaria. J Environ Sci Health Part A 42:1615-1623

Falandysz J, Frankowska A, Jarzyńska G, Dryżałowska A, Kojta AK, Zhang D (2011) Survey on composition and bioconcentration potential of 12 metallic elements in King Bolete (Boletus edulis) mushroom that emerged at 11 spatially distant sites. J Environ Sci Health B 46:231-246

Falandysz J, Kojta AK, Jarzyńska G, Drewnowska A, Dryżałowska A, Wydmańska D, Kowalewska I, Wacko A, Szlosowska M, Kannan K, Szefer P (2012a) Mercury in Bay Bolete Xerocomus badius: bioconcentration by fungus and assessment of element intake by humans eating fruiting bodies. Food Addit Contam A 29:951-961

Falandysz J, Kowalewska I, Nnorom IC, Drewnowska M, Jarzyńska G (2012b) Mercury in Red Aspen Boletes (Leccinum aurantiacum) mushrooms and the soils. J Environ Sci Health Part A 47:16951700

Falandysz J, Nnorom IC, Jarzyńska G, Romińska D, Damps K (2012c) A study of mercury bio-concentration by Puffballs (Lycoperdon perlatum) and evaluation of dietary intake risks. Bull Environ Contam Toxicol 89:759-763

Falandysz J, Widzicka E, Kojta AK, Jarzyńska G, Drewnowska M, Danisiewicz-Czupryńska D, Dryżałowska A, Lenz E, Nnorom IC (2012d) Mercury in Common Chanterelles mushrooms: Cantharellus spp. update. Food Chem 133:842-850

Falandysz J, Mazur A, Kojta AK, Jarzyńska G, Drewnowska M, Dryżałowska A, Nnorom IC (2013) Mercury in fruiting bodies of 
dark honey fungus (Armillaria solidipes) and beneath substratum soils collected from spatially distant areas. J Sci Food Agric 93: $853-858$

Falandysz J, Dryżałowska A, Saba M, Wang J, Zhang D (2014a) Mercury in the fairy-ring of Gymnopus erythropus (Pers.) and Marasmius dryophilus (Bull.) P. Karst. mushrooms from the Gongga Mountain, Eastern Tibetan Plateau. Ecotoxicol Environ Saf 104: $18-22$

Falandysz J, Krasińska G, Pankavec S, Nnorom IC (2014b) Mercury in certain Boletus mushrooms from Poland and Belarus. J Environ Sci Health Part B 49:690-695

Falandysz J, Zalewska T, Krasińska G, Apanel A, Wang Y, Pankavec S (2015a) Evaluation of the radioactive contamination in fungi genus Boletus in the region of Europe and Yunnan Province in China. Appl Microbiol Biotechnol 99. doi:10.1007/s00253-015-6668-0

Falandysz J, Zhang J, Zalewska T, Apanel A, Wang Y, Wiejak A (2015b) Distribution and possible dietary intake of radioactive ${ }^{137} \mathrm{Cs},{ }^{40} \mathrm{~K}$ and ${ }^{226} \mathrm{Ra}$ with the pantropical mushroom Macrocybe gigantea in SW China. J Environ Sci Health A 50:941-945

Falandysz J, Zhang J, Wang Y, Krasińska G, Kojta A, Saba M, Shen T, Li T, Liu H (2015c) Evaluation of the mercury contamination in mushrooms of genus Leccinum from two different regions of the world: accumulation, distribution and probable dietary intake. Sci Total Environ 537:470-478

Fischer RG, Rapsomanikis S, Andreae MO, Baldi F (1995) Bioaccumulation of methylmercury and transformation of inorganic mercury by macrofungi. Environ Sci Technol 29:993-999

García MA, Alonso J, Melgar MJ (2015) Radiocaesium activity concentrations in macrofungi from Galicia (NW Spain): influence of environmental and genetic factors. Ecotox Environ Saf 115:152-158

Gucia M, Jarzyńska G, Rafał E, Roszak M, Kojta AK, Osiej I, Falandysz J (2012) Multivariate analysis of mineral constituents of edible Parasol Mushroom (Macrolepiota procera) and soils beneath fruiting bodies collected from Northern Poland. Environ Sci Poll Res 19:416-431

Guédron S, Tisserand D, Garambois S, Spadini L, Molton F, Bounvilay B, Charlet L, Poly DA (2014) Baseline investigation of (methyl)mercury in waters, soils, sediments and key foodstuffs in the Lower Mekong Basin: the rapidly developing city of Vientiane (Lao PDR). J Geochem Expl 143:96-102

Gumińska B, Wojewoda W (1985) Grzyby i ich oznaczanie. Państwowe Wydawnictwo Rolnicze i Leśne, Warszawa

Jarzyńska G, Falandysz J (2011) The determination of mercury in mushrooms by CV-AAS and ICP-AES techniques. J Environ Sci Health Part A 46:569-573

Jarzyńska G, Falandysz J (2012a) Metallic elements profile of Slate Bolete (Leccinum duriusculum) mushroom and associated soil horizon. J Geochem Expl 121:69-75

Jarzyńska G, Falandysz J (2012b) Metallic elements profile of Hazel (Hard) Bolete (Leccinum griseum) mushroom and associated upper soil horizon. African J Biotechnol 11:4588-4594

JECFA (2010) Joint FAO/WHO Expert Committee on Food Additives. Seventy-second meeting. Rome, 16-25 February 2010. Summary and conclusions. JECFA/72/SC. Food and Agriculture Organization of the United Nations World Health Organization. Issued 16th March 2010

Kojta AK, Jarzyńska G, Falandysz J (2012) Mineral composition and heavy metal accumulation capacity of Bay Bolete (Xerocomus badius) fruiting bodies collected near a former gold and copper mining area. J Geochem Expl 21:76-82

Kojta AK, Wang Y, Zhang J, Li T, Saba M, Falandysz J (2015) Mercury contamination of fungi genus Xerocomus in the Yunnan Province in China and the region of Europe. J Environ Sci Health Part A 50: doi: $10.1080 / 10934529.2015 .1059108$
Krasińska G, Falandysz J (2015) Mercury in Hazel Bolete Leccinum griseum and soil substratum: distribution, bioconcentration and probable dietary exposure. J Environ Sci Health Part A 50:12591264

Larsen EH, Hansen M, Gössler W (1998) Speciation and health risk considerations of arsenic in the edible mushroom Laccaria amethystina collected from contaminated and uncontaminated locations. Appl Organomet Chem 12:285-291

Lassoe T, Del Conte A, Lincoff G (1996) The mushroom book. Kindersley Publishers, New York

Li T, Zhang T, Shen T, Shi Y, Yang S, Zhang T, Li J, Wang Y, Liu H (2013) Mineral element content in prized matsutake mushroom (Tricholoma matsutake) collected in China. Chem Pap 67:672-676

Melgar MJ, Alonso J, Garcia MÁ (2009) Mercury in edible mushrooms and soil. Bioconcentration factors and toxicological risk. Sci Total Environ 407:5328-5334

Mleczek M, Siwulski M, Mikołajczak P, Gasiecka M, Sobieralski K, Szymańczyk M, Goliński P (2015) Content of selected elements in Boletus badius fruiting bodies growing in extremely polluted wastes. J Environ Sci Health Part A 50:767-775

Moore TR, Bubier JJ, Heyes A, Flett RJ (1995) Methyl and total mercury in boreal wetland plants, experimental Lakes Area, Northwestern Ontario. J Environ Qual 24:845-850

Ostos C, Perez-Rodriguez F, Moreno Arroyo B, Moreno-Rojas R (2015) Study of mercury content in wild edible mushrooms and its contribution to the Provisional Tolerable Weekly Intake in Spain. J Food Comp Anal 37:136-142

Nasr M, Arp P (2011) Hg concentrations and accumulations in fungal fruiting bodies, as influenced by forest soil substrates and moss carpets. Appl Geochem 26:1905-1917

Nasr M, Malloch DW, Arp PA (2012) Quantifying Hg within ectomycorrhizal fruiting bodies, from emergence to senescence. Fungal Biol 116:1163-1177

Niedzielski P, Mleczek M, Magdziak Z, Siwulski M, Kozak L (2013) Selected arsenic species: As(III), As(V) and dimethylarsenic acid (DMAA) in Xerocomus badius fruiting bodies. Food Chem 141: 3571-3577

Nnorom IC, Jarzyńska G, Falandysz J, Drewnowska M, Okoye I, OjiNnorom Ch G (2012) Occurrence and accumulation of mercury in two species of wild grown Pleurotus mushrooms from Southeastern Nigeria. Ecotoxicol Environ Saf 84:78-83

Nnorom IC, Jarzyńska G, Drewnowska M, Kojta AK, Pankavec S, Falandysz J (2013) Trace elements in sclerotium of Pleurotus tuber-regium (Ósu) mushroom-dietary intake and risk in Southeastern Nigeria. J Food Comp Anal 29:73-81

Petkovšek SAS, Pokorny B (2013) Lead and cadmium in mushrooms from the vicinity of two large emission sources in Slovenia. Sci Total Environ 443:944-954

Ralston NVC, Raymond LJ (2014) Selenium status and intake influences mercury exposure risk. In: Banuelos GS, Lin Z-Q, Yin X (eds) Selenium in the environment and human health. Taylor \& Francis Group, London, pp 203-205

Řanda Z, Kučera J (2004) Trace elements in higher fungi (mushrooms) determined by activation analysis. J Radioanal Nucl Chem 259:99107

Rieder SR, Brunner I, Horvat M, Jacobs A, Frey B (2011) Accumulation of mercury and methylmercury by mushrooms and earthworms from forest soils. Environ Poll 159:2861-2869

Seeger R, Nützel M (1976) Quecksilbergehalt der Pilze. Z Lebensm Unters-Forsch 160:303-312

Stijve T, Roschnik R (1974) Mercury and methyl mercury content of different species of fungi. Travaux de chimie alimentaire et d'hygične 65:209-220

Stijve T, Vellinga EC, Herrmann A (1990) Arsenic accumulation in some higher fungi. Persoonia 14:161-166 
Stijve T, Noorloos T, Byrne AR, Šlejkovec Z, Goessler W (1998) High selenium levels in edible Albatrellus mushroom. Dtsch Lebensm Rundsch 94:275-279

Tel G, Çavdar H, Deveci E, Öztürk M, Duru ME, Turkoğlub A (2014) Minerals and metals in mushroom species in Anatolia. Food Addit Contam B 7:226-231

Tüzen M, Özdemir M, Demirbaș A (1998) Study of heavy metals in some cultivated and uncultivated mushrooms of Turkish origin. Food Chem 61:247-251

UNEP (2013) Mercury - time to act. United Nations Environmental Programme, 2013. http://www.unep.org/PDF/PressReleases/ Mercury_TimeToAct.pdf

US EPA (1987) United States environmental Protection Agency peer review workshop on mercury issues. Summary report. Environmental criteria and assessment office. U.S. EPA, Cincinnati

Varo P, Lähelmä O, Nuurtamo M, Saari E, Koivistoinen P (1980) Mineral element composition of Finnish foods. VII. Potato, vegetables, fruits, berries, nuts and mushrooms. Acta Agric Scand 22:89-113
Wang X, Zhang J, Wu L, Zhao Y, Li T, Li J, Wang Y, Liu H (2014) A mini-review of chemical composition and nutritional value of edible wild-grown mushroom from China. Food Chem 151:279-285

Wang Y, Zalewska T, Apanel A, Zhang J, Wiejak A, Falandysz J (2015) ${ }^{137} \mathrm{Cs},{ }^{134} \mathrm{Cs}$ and natural ${ }^{40} \mathrm{~K}$ in sclerotia of Wolfiporia extensa fungus collected across of the Yunnan land in China. J Environ Sci Health Part B 50:654-658

WHO (2000) World Health Organization, Chapter 6.9 mercury air quality guidelines - second edition WHO Regional Office for Europe, Copenhagen, Denmark, 2000. http://www.euro.who.int/ data/ assets/pdf_file/0004/123079/AQG2ndEd_6_9Mercury.PDF

Zhang D, Frankowska A, Jarzyńska G, Kojta AK, Drewnowska M, Wydmańska D, Bielawski L, Wang J, Falandysz J (2010) Metals of King Bolete (Boletus edulis) collected at the same site over two years. African J Agricult Res 5:3050-3055

Zhang H, Feng X, Chan H-M, Larssen T (2014) New insights into traditional health risk assessments of mercury exposure: implications of selenium. Environ Sci Technol 48:1206-1212 